\title{
Risk Effect Of IT Outsourcing On Firm Performance And Value
}

Pushpa Agrawal, Singhania University, India

Abid Haleem, Ph.D., Jamia Millia Islamia, India

\begin{abstract}
This study examines the risk effect of IT outsourcing on firm performance and value in different types of contracts categorized by contract value and contract term. We used audited financial data to investigate the impact of IT outsourcing on firms' performance and value. We examined the performance and value in a sample of 90 publicly traded firms that outsourced their IT activities between 1986 and 2009, over a four-quarter period following the outsourcing announcements. Our findings confirm the trend of shrinking outsourcing contract value and term in reality. The results reveal that short-term and low-weight IT outsourcing contracts improve firms' performance more than long-term and high-weight contracts.
\end{abstract}

Keywords: Information Technology (IT); Outsourcing; Risk Effect of IT Outsourcing

\section{INTRODUCTION}

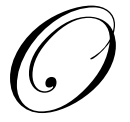

utsourcing is being described as the practice of allocating all or parts of the business activities of the organization to an external source if necessary to create or protect firm value. Outsourcing is now used for a variety of business processes, while initially it was mainly focused on non-core activities.

In outsourcing Information Technology (IT), firms transfer their IT resources, including assets and staffs, to third-party vendors for delivering IT functions ranging from infrastructure to software development, systems operations, maintenance, support, and network management (Hall and Liedtka 2005).

The role of IT has been increasing over the last twenty years in business organizations. Gartner made a forecast for worldwide IT spending, saying it will grow 7.1 percent this year to US\$3.7 trillion (Shah 2011). Gartner (2011) predicted that IT spending would grow worldwide approximately 5\% per year through 2015. In recent years, firms in various sectors use outsourcing as a means to manage their IT operations (Wang et al. 2008). The main outsourcing concerns are the reduction in operating cost, ensuring the availability of high quality goods and service, the focus on core competency, improving companies' flexibility, and ambitions to learn from innovative suppliers (Bengtsson and Dabhilkar 2009).

In spite of several benefits, IT outsourcing is associated with a number of risk factors (Aubert et al.1999: Earl 1996). Outsourcing does not always guarantee competitive advantage to the firm (Grover et al. 1996). Subjective assessments are used in IT outsourcing engagements because services are complex, intangible, and heterogeneous in nature; thus objective decision criteria may not be easily available in a reasonable manner (Boehm 1981; Lacity and Hirschheim 1993). It is assumed that managerial estimates of performance are consistent with objective outcome criteria. These subjective judgments, while useful and important, also raise the several issues of bias inherent in judgment tasks and the risk that cognitive bias may harm subjects' ability to form accurate judgments (Ramchandran and Gopal 2010). Furthermore, subjective judgments of performance depend on input information. Sometimes information does not represent the most accurate, timely, relevant, or suitable into the judgment tasks and the resulting outcome is ambiguous or may be inconsistent with objective outcomes.

The increase in offshore outsourcing activities is due to economic globalization and the emergence of extended enterprises derived from interrelationships among organizations (Dou and Sarkis 2010). In addition to the 
risks inherent in outsourcing, offshoring poses additional risks such as cultural differences, language barriers, and geographical and time zone related barriers (Chen et al. 2002; Evaristo et al. 2005). Furthermore, there are also foreign exchange risks, political risks, and legal risks associated with offshoring (Dou and Sarkis 2010).

In this research we used audited financial data (cost efficiency, productivity, profitability, growth, cash management, and market ratio, as well as market value, using financial metrics) to examine risk effect on firm performance following IT outsourcing. We measured a contract risk level by its contract value and term. Generally, higher contract value and a longer contract term make the contract implementation more complex, compared to lower contract value and a short-term contract.

This paper is organized as follows: (II) a review of outsourcing's risks; (III) the conceptual framework and hypothesis development; (IV) the research methodology; (V) the results; and (VI) the conclusion.

\section{RISK OF IT OUTSOURCING}

There are several risks in outsourcing, such as unexpected escalated costs, disputes and litigations, lock-ins, and loss of organizational competencies resulting in undesirable outcomes (Aubert et al. 1999, Bahli and Rivard 2003).

\section{Risk in IT outsourcing}

Lack of organizational learning and loss of innovative capacity

Organizations learn about the management and capability of IT by doing or by experience. IT outsourcing firms may not very well understand future technologies offered by a vendor unless they have in-house exposure to earlier versions of the same technology (Earl 1996). Outsourcing can generate new risk such as loss of critical skills, developing the wrong skills, and the loss of cross-functional skills (Domberger 1998; Quinn and Hilmer 1994). As outsourcing firms lose internal IT skills over time, monitoring contracts becomes more difficult and more expensive (Windrum et al. 2009). It is important to synchronize between a firm's IT strategic planning and its business planning. IT outsourcing will result in misalignment between IT strategic planning and business strategy and thus degenerate the performance of the organization. In the long - run, firms want to maintain IT innovative capacity for competitiveness (Teece 1987).

In outsourcing IT, however, firms may lose touch with technological breakthroughs that offer opportunity for innovation capacity and capabilities. A vendor does not guarantee all the attributes of innovation such as slack resources, organic and fluid organizational processes, and experimental and entrepreneurial competences (Earl 1996). The outsourcing vendors are inclined to provide a "one-size fits all" strategy to different competitive client organizations, rather than providing integrative solutions tailored to the needs of the individual users (Hall et al. 2005).

\section{Eventual competition from supplier}

IT vendors, after learning from the outsourcing firm, are likely to market the applications to other customers on their own (Prahalad and Hamel 1990).

High cost of switching of IT vendors

Once the outsourcing firm divests itself of its specific IT assets, the vendor can exploit a client's dependency, because it is difficult to rehire skilled IT staff and costly to purchase new IT systems and train general staff (Hall et al. 2005). In case of new requirements, the vendor can negotiate the service rates at a premium because IT suppliers are not turn-key and they are not easily substituted, as markets are thin. Generally, in a long-term contract, the outsourcing firm has more leverage in negotiations; but the vendor has more leverage after outsourcing is under way (Windrum et al. 2009). 


\section{Loss of control}

Outsourcing firms may transfer critical functions to IT suppliers or become too dependent on them for dayto-day performance of vital business functions. Furthermore, if the information is forwarded to third party IT vendors, then it is difficult for outsourcing firms to protect personal data. Patent laws do not protect data available in the physical product and its design (Hall et al. 2005). Outside vendors cannot match the responsibility and service level achieved by an internal IT department. Outsourcing firms do not have the same management direction and control over vendors as they have over their own employees (Lacity and Willcocks 1996).

\section{Harmful to employee morale}

Outsourcing redefines organizational boundaries and business structure involving human resources. Outsourcing firms may lay off employees or transfer employees to vendors, incurring social and financial costs. Outsourcing also can result in industrial disputes between employers and employees, which in turn can damage morale, trust, and productivity (McCarthy and Anagnostou 2003).

\section{Hidden costs}

Outsourcing is based on the assumption that the supplier's costs and required contribution is less, and will continue to be less, than the costs of internal provision. PA Consulting Group (PACG) surveyed 1000 managers worldwide and found that only 5\% of organizations gained "high" levels of economic benefits from outsourcing, $39 \%$ of organizations admitted "mediocre" economic benefit, and the remaining $56 \%$ said they received no benefits (PA Consulting Group (PACG), 1996). Outsourcing firms often fail to anticipate the management costs and the costs of vendor selection, contracting, and transferring of IT operations to the vendor, and these costs become apparent only after the vendor takes control of the IT assets (Barthelemy 2001).

\section{Technological complexity}

There is an ambiguity associated with the process of converting vague and changing clients' needs into the final software output, and also, frequent design changes increase the requirement volatility associated with the project. Typically, a vendor project portfolio is a mix of maintenance and reengineering projects, as well as a varied set of complex applications development and management, and product implementation tasks because vendors have several projects (Ramchandran and Gopal 2010). Vendors try to standardize the applications of various clients on a common platform. The more technologically sophisticated the required hardware and software infrastructure for the project, the greater the risk of technical problems (Ramchandran and Gopal 2010).

\section{Risks in IT offshoring}

The clients often end up in messier situations after offshoring than before they began. Mucisko \& Lum (2005) stated that $70 \%$ of outsourcing clients had negative experiences with outsourcing and $25 \%$ of clients brought outsourcing services back in-house. In addition to the risks in outsourcing, offshoring poses additional risks such as cultural differences, language barriers, and geographical and time zone related barriers (Chen et al. 2002; Evaristo et al. 2005). Furthermore, there are also foreign exchange risks, political risks, and legal risks associated with offshoring (Dou and Sarkis 2010).

The evidence in the case of Dell was documented by CNN (CNN November 25, 2003); the computer maker stopped using a technical support center in India to handle calls from its corporate customers after complaints of difficulties in communications because of thick accents and scripted responses. In Western countries and especially in the US, significant concern has been generated in the public arena over the consequences of offshore outsourcing for American jobs. In the 2004 and 2008 presidential elections, the "outsourcing of American jobs overseas" became a debated issue (Paul and Wooster 2010). A number of US states, including Ohio and Connecticut, have passed legislation to restrict offshoring. 


\section{THE CONCEPTUAL FRAMEWORK AND HYPOTHESIS DEVELOPMENT}

Legorreta and Goyal (2007) stated that the risk of outsourcing involves five dimensions describing outsourcing arrangements: ownership of IT assets, degree, mode, timeframe, and location. Ownership of IT assets and degree are the percentage of IT assets owned by the customer. Risk increases as more and more IT asset ownership is transferred to the supplier. These terms also describe the value of the outsourcing contract, such as high-value and low-value IT outsourcing contracts. Mode refers to different client and supplier configurations, such as single client - single vendor, multiple clients - single vendor, single client - multiple vendors, and multiple clients - multiple vendors. Different configurations have different associated levels of risks. Timeframe of IT outsourcing projects can be either short-term (1year or 2 years), mid-term (3 to 5 years), or long-term (10 years or longer). Location is the place where resources will be located.

If risks are not managed properly, it can eliminate the benefit of outsourcing partially or totally. Outsourcing with a single vendor, under a fixed-priced, exchange-based, and long-term contract may sometimes make sense at the beginning of the contract, but not make sense three years later. Customers often had to renegotiate and even terminate their contracts mid-stream (Lacity et al. 2001). Firms then signed selective outsourcing contracts with multiple vendors to mitigate the risk of total outsourcing. The success rate for this strategy was higher than when a contract was signed with a single vendor. However, the transaction cost with multiple vendors also increased, and therefore it becomes important to manage the risk, no matter what kind of outsourcing configuration is used.

There is no step-by-step procedure for controlling risks over every outsourcing instance. The best way to manage all risks is through firm-vendor partnership (psychological contracts). The list of best practices for managing the risks is (Legorreta and Goyal 2007):

- $\quad$ Negotiate short-term contracts or renew contracts periodically to improve flexibility.

- Include a provision in the contract to terminate the contract with a smooth transition.

- Use a pilot project.

- $\quad$ Build experience by incremental outsourcing.

- $\quad$ Retain key capabilities in-house while outsourcing technology tasks.

- $\quad$ Establish a pricing strategy which encourages innovation.

- $\quad$ Hire an intermediary consulting firm.

- $\quad$ Manage performance through well-constructed metrics.

- $\quad$ Hire a legal expert to mitigate legal risks.

- $\quad$ Create a centralized program management office to consolidate management.

As stated above, in this research we examined hard data to evaluate the risk effect on firm performance after outsourcing announcements. We measured a contract risk level by its value and term. Generally higher contract value and a longer contract term make the contract implementation more complex, compared to lower contract value and a short-term contract. Functional complexity precipitates difficult contracting, which drives up transaction costs. The risk of the contract increases with the degree of complexity. A short-term outsourcing contract can help outsourcing firms adjust to market changes and new technology opportunities. A low-value contract is more adaptable to unexpected changes and will have a lower impact on an outsourcing firm's structure, culture, and employee arrangements. A short-term and low-value outsourcing contract will not bring fatal damages to a firm's outsourced strategic activities, or if the non-strategic activities become strategic at a later date. Furthermore, shortterm or low-value outsourcing contracts can reduce the outsourcing firm's loss if the vendor goes out of business or a vendor's technology becomes obsolete.

Therefore, we used outsourcing contract value and term to measure an IT outsourcing contract risk level. Our research hypotheses on risk control are:

H1a: The firm that enters into a low-weight IT outsourcing contract will see a bigger improvement in firm performance than the firm that enters into a high-weight contract. 
H1b: The firm that enters into a short-term IT outsourcing contract will see a bigger improvement in firm performance than the firm that enters into a long-term contract.

H1c: The lower the value of an IT outsourcing contract, the greater the increase in the market value of the firm.

H1d: The shorter the length of an IT outsourcing contract, the greater the increase in the market value of the firm.

\section{RESEARCH METHODOLOGY}

In this study we examined risk effect on firm performance following IT outsourcing. We used publicly available audited financial data to test contract risk level by its contract value and term over a four-quarter period after the outsourcing announcements.

\section{Sample and Data Source}

We used the Factiva database to search for IT outsourcing announcements in two media: The Wall Street Journal (Beaver 1998) and the Dow Jones Publications (Hendricks and Singhal 2003). We included samples of firms publicly announcing an IT outsourcing contract from January 1, 1986 to September 30, 2009. Keywords "outsourcing OR offshoring" AND "announcement OR contract OR deals" combinations of the search item are used to search the IT outsource announcements. We selected "Corporate/Industrial News" in the subject category and "Contract/Order" in its sub category. Then we chose "North American Countries" in the region category and "USA" in its sub category.

Initially we obtained 293 announcements, including multiple announcements for a few companies. For example, a single company can make one announcement in 1998 and another in 2002. We were careful to maintain a gap between the announcements so that the effect of the first announcement does not affect the performance result of second announcement. We examined publicly traded firms that trade on US Stock exchanges such as the New York Stock Exchange (NYSE), National Association of Securities Dealers Automated Quotations (NASDAQ), and American Stock Exchange (AMEX). Generally, these are large size firms and therefore a small outsourcing contract does not affect them significantly. We selected IT outsourcing announcements of $\$ 5$ million or more. We excluded the firms that outsourced telecommunication services because firms routinely outsource such services.

It is necessary to remove the firms that announce lawsuits, strikes, acquisitions, and merger etc. in a window of 4 quarters after the outsourcing announcement to eliminate the effect of such other announcements. To search such announcements we used the Factiva database using the keyword treatment firm's name and one year post-event period. We had 144 announcements after this process. We used publicly audited financial data from the COMPUSTAT database. We collected the data for the quarter in which firms announced the decision to outsource their IT activities. We also collected the data for four quarters after the announcements. We did not find data in COMUSTAT for 54 firms, therefore we eliminated those firms. Finally we had 79 firms and 90 announcements (Table 1). In our paper we used 90 firms for 90 announcements. Out of seventy-nine firms, forty-five firms were in agriculture or manufacturing industries (Standard Industrial Classification (SIC) codes under 5000), and thirty-four firms are in service industries (SIC codes from 5000 and higher) (Table 2).

Table 1: Sample Size

\begin{tabular}{lc}
\hline Sample size from announcements & 293 \\
Less: Announcements impacted by other news such as Strikes, Lawsuits, merger, & -149 \\
acquisition etc. & -54 \\
Less: Data not found on COMPUSTAT Database & $90(79$ firms $)$ \\
Final sample size & \\
\hline
\end{tabular}


Table 2: Distribution of Treatment Firms by Industry

\begin{tabular}{llc}
\hline SIC Codes & Industry Category & Number of Firms \\
\hline $0001-999$ & Agriculture & 1 \\
$1000-1999$ & Natural resources & 1 \\
$2000-2099$ & Food & 1 \\
$2600-2799$ & Paper and Publishing & 2 \\
$2800-2999$ & Chemicals and Petroleum & 9 \\
$3000-3569,3580-3659,3800-3999$ & Rubber, Leather, Stone, Metal, Machinery, Equipment & 5 \\
$3570-3579,3660-3699,3760-3789$ & Computers, Communications, Electronics & 6 \\
$3700-3759,3790-3799$ & Automobiles, Aircraft, Transportation & 5 \\
$4000-4999$ & Logistics, Supply & 15 \\
$5000-5199$ & Wholesale & 1 \\
$5200-5999$ & Retailing & 6 \\
$6000-6299$ & Financial & 7 \\
$6300-6499$ & Insurance & 5 \\
$7200-7320$ & Personal and Business Services & 2 \\
$7370-7373$ & Computer and Software Services & \\
$7510-7549$ & Automotive repair, services, and parking & 1 \\
$8011-8099$ & Health services & 5 \\
$9000-9999$ & Not classified & 2 \\
Total & & 79 \\
\hline
\end{tabular}

An IT outsourcing contract value (\$5million or more) was selected for our study. Our sample represented the length of contract from 1 year to 15 years (term). The descriptive statistics of contract values and terms are given in Table 3.

Table 3: Descriptive Statistics of Outsourcing Contract Value and Length of Contract

\begin{tabular}{lcc}
\hline Statistics & Outsourcing Contract Value (million \$) & Outsourcing Contract Terms (Year) \\
\hline & & 7.09 \\
Mean & 738.68 & 0.30 \\
Standard Error of Mean & 123.53 & 7.00 \\
Median & 256.50 & 10 \\
Mode & 500,1100 (Multiple mode) & 2.82 \\
Standard Deviation & 1171.88 & 7.94 \\
Variance & 1373313.10 & 14 \\
Range & 6395 & 1.00 \\
Minimum & 5.00 & 15 \\
Maximum & 6400 & \\
\hline
\end{tabular}

\section{Performance Metrics}

In this study we derived six performance metrics: cost efficiency, productivity, profitability, growth, cash management, and market ratios (Smith et al. 1998).

Cost efficiency

There are two ratios as a percentage of sales: SG\&A (selling, general and administrative expenses)/Sales and Operating Expense (SG\&A + cost of goods sold)/Sales.

\section{Productivity}

There are three productivity ratios: Assets Turnover (sales/average assets), PPE Turnover (sales/property, plan, and equipment), and Inventory Turnover (cost of goods sold/average inventory). 


\section{Profitability}

There are three profitability measures: Return on Assets (income before taxes, depreciation, and extraordinary items/average assets), Return on Equity (net income/average common stockholder's equity), and Net Profit Margin (income before taxes, depreciations, and extraordinary items/sales).

Growth

The only growth ratio is a percentage change in Sales per Year.

\section{Cash management}

There are four cash management measures: total liability as a percentage of sales, long-term debt as a percentage of sales, current liability as a percentage of sales, and financial leverage (total liabilities/common stockholder's equity).

\section{Market ratios}

The measure used was dividends paid to the shareholders as a percentage of sales.

In the study, we considered the quarter in which the firm announced its IT-outsourcing agreement to be Quarter (Q) 0. The first quarter, second quarter, third quarter, and fourth quarter after the announcement are Quarter 1, Quarter 2, Quarter 3 and Quarter 4 respectively. We analyzed the change in performance over the quarter intervals and calculated the changes in performance (Jiang et al. 2006) for evaluating risk levels as follows:

Change percentage $=[$ Metric@Q(i) - Metric@Q(0)]/[Metric@Q(0)].

To test the changes in post-outsourcing quarters we examined the percentage change in performance from Quarter 0 to Quarter 1, Quarter 0 to Quarter 2, Quarter 0 to Quarter 3, and Quarter 0 to Quarter 4. We calculated the change rate for each post-event quarter to the original point $\mathrm{Q}(0)$ because there would be no significant change from quarter to quarter such as $\mathrm{Q}(0)$ to $\mathrm{Q}(1), \mathrm{Q}(1)$ to $\mathrm{Q}(2)$, and so on.

\section{Risk control}

There are two risks involved in outsourcing: amount of contract and length of contract. In our study, we divided IT outsourcing contracts into high-value and low-value categories. The absolute outsourcing contract value cannot indicate real importance to the firm without the reference of a firm's size. We used Weight (=Net Present Value (NPV) of a contract value/Asset value in Quarter (0)) to measure an outsourcing contract's relative value. We used 5\% as the discount rate to calculate NPV of the contract amount. For example, Halliburton Company had total assets $\$ 5,104.1$ million in Quarter 0, the contract value $\$ 500$ million, and the contract term 10 years.

$$
\begin{aligned}
\mathrm{NPV} & =[500] /[1+.05]^{10} \\
& =\$ 306.95 \text { million }
\end{aligned}
$$

The relative weight of this contract value is:

$$
\begin{aligned}
\text { Weight } & =\text { NPV/Total Assets } \\
& =306.95 / 5104.1 \\
& =0.06
\end{aligned}
$$

We considered high weight (larger than 0.1) and low weight (lower than or equal to 0.1 ) and we got 48 high-weight firms and 42 low-weight firms.

We divided length of outsourcing contract into long-term and short-term categories. For this process we took a mean ( 7.08 years) of contract term and considered long-term as more than 7 years and short-term as less than or equal to 7 years. On this basis we have 38 long-term contracts and 52 short-term contracts. 


\section{Abnormal market return}

We used the event study methodology to examine the effect of contract value and contract term on IT outsourcing firms' value. An event study measures the impact of a specific event on the value of a firm (Hayes et al. 2000). We measured market value by using abnormal market returns, because they capture changes in market value in excess of normal expected returns. The market model assumes a linear relationship between the return of any security and the return of the market portfolio. The market model is:

$\mathrm{R}_{\mathrm{it}}=\alpha_{\mathrm{i}}+\beta_{\mathrm{i}} \mathrm{R}_{\mathrm{mt}}+\varepsilon_{\mathrm{it}}$

Where

$\mathrm{R}_{\mathrm{it}}=$ the rate of return for firm $\mathrm{i}$ at time $\mathrm{t}$,

$\alpha_{\mathrm{i}}$ and $\beta_{\mathrm{i}}=$ the market model parameters for firm I,

$\mathrm{R}_{\mathrm{mt}}=$ the rate of return on a market portfolio over period $\mathrm{t}$, and

$\varepsilon_{\mathrm{it}}=$ the disturbance term.

In our study we used Eventus software to calculate the abnormal returns. Eventus performs event studies using data read directly from CRSP stock databases or pre-extracted from any source. Eventus provides user control over estimation periods and cumulative return windows; a choice of raw, comparison-period-mean-adjusted, marketadjusted or market-model-abnormal returns.

Using the software, we measured the event impact of IT outsourcing by calculating abnormal return $\left(\mathrm{AR}_{\mathrm{it}}\right)$ using a formula for firm $\mathrm{i}$ and event date $\mathrm{t}$ :

$A R_{i t}=R_{i t}-\alpha_{i}-\beta_{i} R_{m t}$

We considered the month in which the firm announces its IT outsourcing agreement as month 0 . We selected a wide event window, from -1 month to +12 months to examine the impact of IT outsourcing on each firm's stock value.

\section{RESULTS}

\section{Binomial Test}

We have divided our outsourcing firms by weight (high and low) and by term (long and short) to examine the effect of both weight and term on outsourcing firms' performance and value. We have 48 high-weight firms, 42 low-weight firms, 38 long-term contract firms, and 52 short-term contract firms. We used the binomial test method (Bandwin and Glezen 1992; Barth et al. 2001) to test whether more than 50\% of the firms in a sub-sample have improved their performance after IT outsourcing. We defined an improved result as success and an unimproved result as failure. We ran a lower-tailed binomial test to determine success or failure for each sub-sample at 0.1 significance level.

Table 4 shows no improvement for 11 high-weight sub-samples and 6 low-weight sub-samples. That means that the high-weight IT outsourcing contracts more likely do not improve outsourcing firms' performance during the four-quarter period and have a relatively higher risk than low-weight outsourcing contracts.

Table 5 shows no improvement for 11 long-term sub-samples and 10 short-term sub-samples. The results show a marginal difference between long-term and short-term contracts with a little support for short-term contract.

The results support the trend of shrinking outsourcing contract value and term in reality. Consultants often recommend three years as the optimum period for the length of an outsourcing contract (Johnson 2000). Outsourcing contract granting firms usually want to change the pricing structure of the deal and certain aspects of the technology being supplied. However, vendors, after getting a contract, do not want to change anything that would affect their 
profit margin (Johnson 2000). An IT outsourcing contract for more than three years is not usually feasible in this era of fast-changing technology.

We can conclude that a low-weight and short-term IT outsourcing contract will have better performance than a high-weight and long-term contract. Thus, the evidence supports hypothesis H1a and H1b.

Table 4: Binomial Test Results by Weight

\begin{tabular}{|c|c|c|c|c|c|c|c|c|c|c|c|c|}
\hline & \multirow{2}{*}{$\begin{array}{c}\text { Sign for no } \\
\text { improvement }\end{array}$} & & \multicolumn{2}{|c|}{ Q1 } & \multicolumn{2}{|c|}{ Q2 } & \multicolumn{2}{|c|}{ Q3 } & \multicolumn{2}{|c|}{ Q4 } & \multicolumn{2}{|c|}{ Average } \\
\hline & & & High & Low & High & Low & High & Low & High & Low & High & Low \\
\hline \multirow{2}{*}{ SG\&A/Sales } & \multirow[t]{2}{*}{$>0$} & $<=0$ & 12 & 15 & 17 & 17 & 14 & 15 & 21 & 14 & 18 & 26 \\
\hline & & $>0$ & $24 * *$ & 12 & 19 & 10 & 22 & 10 & 15 & 11 & 18 & 11 \\
\hline \multirow{2}{*}{$\begin{array}{l}\text { Operating } \\
\text { Expense/Sales }\end{array}$} & \multirow[t]{2}{*}{$>0$} & $<=0$ & 13 & 18 & 21 & 16 & 16 & 13 & 12 & 15 & 21 & 17 \\
\hline & & $>0$ & $23 *$ & 9 & 15 & 11 & 26 & 12 & 24 & 10 & 15 & 10 \\
\hline \multirow[t]{2}{*}{ Asset Turnover } & \multirow[t]{2}{*}{$<=0$} & $<=0$ & 23 & 20 & 18 & 21 & 24 & 15 & 19 & 18 & 21 & 16 \\
\hline & & $>0$ & 23 & 17 & 28 & 16 & 21 & 21 & 26 & 17 & 25 & 21 \\
\hline \multirow[t]{2}{*}{ PPE Turnover } & \multirow[t]{2}{*}{$<=0$} & $<=0$ & 24 & 15 & 17 & 18 & 20 & 11 & 18 & 12 & 17 & 15 \\
\hline & & $>0$ & 22 & 20 & 30 & 17 & 26 & 23 & 27 & 21 & 30 & 20 \\
\hline \multirow{2}{*}{$\begin{array}{l}\text { Inventory } \\
\text { turnover }\end{array}$} & \multirow[t]{2}{*}{$<=0$} & $<=0$ & 21 & 19 & 13 & 15 & 19 & 14 & 17 & 16 & 16 & 16 \\
\hline & & $>0$ & 14 & 14 & 22 & 18 & 15 & 18 & 17 & 15 & 19 & 17 \\
\hline \multirow[t]{2}{*}{ Return on Assets } & \multirow[t]{2}{*}{$<=0$} & $<=0$ & 21 & 16 & 15 & 18 & 17 & 17 & 19 & 20 & 17 & 18 \\
\hline & & $>0$ & 19 & 18 & 25 & 16 & 22 & 16 & 19 & 12 & 23 & 17 \\
\hline \multirow[t]{2}{*}{ Return on Equity } & \multirow[t]{2}{*}{$<=0$} & $<=0$ & 27 & $26 * *$ & 25 & 21 & $28 *$ & 22 & $31 * *$ & 19 & $29 *$ & 22 \\
\hline & & $>0$ & 20 & 13 & 21 & 18 & 17 & 16 & 13 & 18 & 18 & 17 \\
\hline \multirow{2}{*}{$\begin{array}{l}\text { Operating } \\
\text { Margin }\end{array}$} & \multirow[t]{2}{*}{$<=0$} & $<=0$ & 20 & 12 & 16 & 13 & 19 & 12 & 14 & 12 & 16 & 12 \\
\hline & & $>0$ & 16 & 15 & 20 & 14 & 17 & 14 & 21 & 13 & 20 & 15 \\
\hline \multirow{2}{*}{$\begin{array}{l}\text { Net Profit } \\
\text { Margin }\end{array}$} & \multirow[t]{2}{*}{$<=0$} & $<=0$ & 20 & 15 & 17 & 15 & 19 & 15 & 16 & 14 & 16 & 15 \\
\hline & & $>0$ & 20 & 17 & 23 & 16 & 20 & 15 & 22 & 15 & 24 & 17 \\
\hline \multirow[t]{2}{*}{ Growth (Sales) } & \multirow[t]{2}{*}{$<=0$} & $<=0$ & $32 * * *$ & $33 * * *$ & 31** & $30 * * *$ & $32 * * *$ & $28 * * *$ & $34 * * *$ & 21 & $32 * * *$ & $34 * * *$ \\
\hline & & $>0$ & 15 & 6 & 16 & 9 & 14 & 9 & 12 & 16 & 15 & 5 \\
\hline \multirow[t]{2}{*}{ Total Liab/Sales } & $>0$ & $<=0$ & 27 & 18 & 35 & 16 & 26 & 19 & 28 & 15 & 31 & 18 \\
\hline & & $>0$ & 20 & 19 & 12 & 21 & 20 & 16 & 17 & 20 & 16 & 19 \\
\hline LongTerm & $>0$ & $<=0$ & 26 & 18 & 30 & 20 & 25 & 19 & 25 & 20 & 27 & 20 \\
\hline Debt/Sales & & $>0$ & 18 & 19 & 14 & 17 & 18 & 17 & 17 & 15 & 17 & 17 \\
\hline Current & $>0$ & $<=0$ & 21 & 10 & 29 & 14 & 21 & 15 & 26 & 10 & 24 & 13 \\
\hline Liab/Sales & & $>0$ & 22 & 17 & 14 & 13 & 21 & 10 & 15 & 15 & 19 & 14 \\
\hline Financial & $>0$ & $<=0$ & 29 & 16 & 31 & 20 & 31 & 23 & 32 & 24 & 35 & 22 \\
\hline Leverage & & $>0$ & 19 & 23 & 17 & 19 & 16 & 14 & 14 & 13 & 13 & 17 \\
\hline Dividend/Sales & $<=0$ & $<=0$ & 11 & $20 *$ & $13 * *$ & 15 & 9 & 14 & 7 & 14 & 10 & 15 \\
\hline & & $>0$ & 6 & 11 & 4 & 16 & 7 & 14 & 9 & 14 & 7 & 16 \\
\hline
\end{tabular}

The symbols *,**, and $* * *$ denote statistical significance at the $0.10,0.05$, and 0.01 levels, respectively, using a generic one-tail test.

Table 5: Binomial Test Results by Term

\begin{tabular}{|c|c|c|c|c|c|c|c|c|c|c|c|c|}
\hline & \multirow{2}{*}{$\begin{array}{c}\text { Sign for no } \\
\text { improvement }\end{array}$} & & \multicolumn{2}{|c|}{ Q1 } & \multicolumn{2}{|c|}{ Q2 } & \multicolumn{2}{|c|}{ Q3 } & \multicolumn{2}{|c|}{ Q4 } & \multicolumn{2}{|c|}{ Average } \\
\hline & & & Long & Short & Long & Short & Long & Short & Long & Short & Long & Short \\
\hline \multirow[t]{2}{*}{ SG\&A/Sales } & \multirow[t]{2}{*}{$>0$} & $<=0$ & 10 & 17 & 10 & 24 & 11 & 18 & 12 & 23 & 10 & 24 \\
\hline & & $>0$ & 14 & 22 & 14 & 15 & 13 & 19 & 12 & 14 & 14 & 15 \\
\hline \multirow{2}{*}{$\begin{array}{l}\text { Operating } \\
\text { Expense/Sales }\end{array}$} & \multirow[t]{2}{*}{$>0$} & $<=0$ & 14 & 17 & 15 & 22 & 13 & 16 & 13 & 24 & 14 & 24 \\
\hline & & $>0$ & 10 & 22 & 9 & 17 & 11 & 21 & 11 & 13 & 10 & 15 \\
\hline \multirow[t]{2}{*}{ Asset turnover } & \multirow[t]{2}{*}{$<=0$} & $<=0$ & 16 & 27 & 11 & $28 *$ & 17 & 22 & 17 & 20 & 13 & 24 \\
\hline & & $>0$ & 21 & 19 & 26 & 18 & 19 & 23 & 19 & 24 & 24 & 22 \\
\hline \multirow[t]{2}{*}{ PPE Turnover } & \multirow[t]{2}{*}{$<=0$} & $<=0$ & 14 & 25 & 13 & 22 & 13 & 18 & 12 & 18 & 10 & 22 \\
\hline & & $>0$ & 22 & 20 & 23 & 24 & 22 & 27 & 23 & 25 & 26 & 24 \\
\hline \multirow{2}{*}{$\begin{array}{l}\text { Inventory } \\
\text { Turnover }\end{array}$} & \multirow[t]{2}{*}{$<=0$} & $<=0$ & $20 * *$ & 20 & 12 & 16 & 17 & 16 & 16 & 17 & 15 & 17 \\
\hline & & $>0$ & 9 & 19 & 17 & 23 & 11 & 22 & 12 & 20 & 14 & 22 \\
\hline \multirow[t]{2}{*}{ Return on Assets } & \multirow[t]{2}{*}{$<=0$} & $<=0$ & 12 & $25 * *$ & 9 & $24 *$ & 16 & 18 & 17 & 22 & 13 & 22 \\
\hline & & $>0$ & 24 & 13 & 26 & 15 & 18 & 20 & 17 & 14 & 23 & 17 \\
\hline \multirow[t]{2}{*}{ Return on Equity } & \multirow[t]{2}{*}{$<=0$} & $<=0$ & 21 & $32 * *$ & $25^{* *}$ & 21 & $30 * * *$ & 20 & $24 * *$ & 26 & $25 * *$ & 26 \\
\hline & & $>0$ & 17 & 16 & 13 & 26 & 6 & 27 & 13 & 18 & 13 & 22 \\
\hline \multirow{2}{*}{$\begin{array}{l}\text { Operating } \\
\text { Margin }\end{array}$} & \multirow[t]{2}{*}{$<=0$} & $<=0$ & 8 & $24 *$ & 9 & 20 & 11 & 20 & 11 & 15 & 10 & 18 \\
\hline & & $>0$ & 16 & 15 & 15 & 19 & 13 & 18 & 13 & 21 & 14 & 21 \\
\hline
\end{tabular}


Table 5: continued

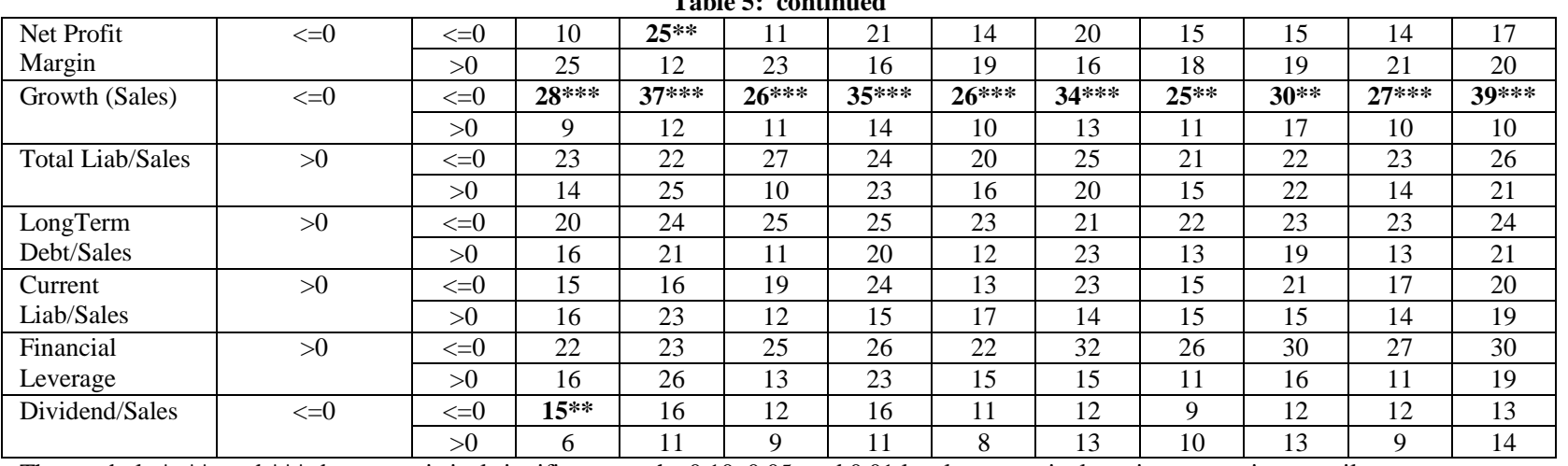

The symbols *,**, and *** denote statistical significance at the $0.10,0.05$, and 0.01 levels, respectively, using a generic one-tail test.

\section{Firm's Value}

We also examined the effect of both weight (high-weight and low-weight) and term (long-term and shortterm) on outsourcing firms' value. The outsourcing impact on a firm's stock price is likely to vary with different types of outsourcing contracts such as high- weight, low-weight, long-term, and short-term. Figure 1, figure 2, table 6 , and table 7 show the result of abnormal return for the firms having high-weight, low-weight, long-term, and shortterm contracts from -1 month to +12 months. We consider the outsourcing event occurs in month 0 .

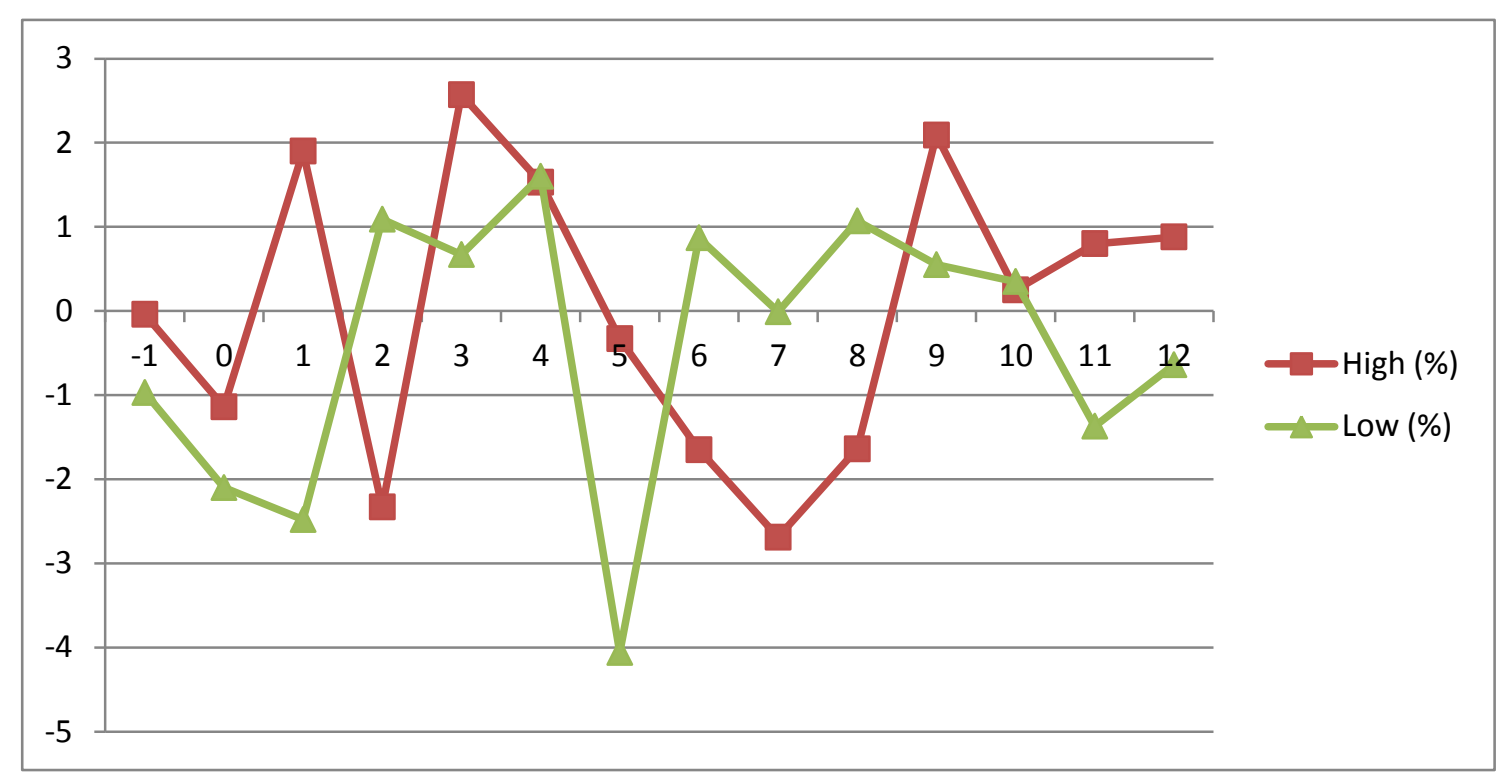

Figure 1: Trend of Abnormal Return Rate by Weight

According to figure 1 the impact of high-weight IT outsourcing contracts on outsourcing firms' abnormal rate of return is higher in most situations, but in some situations it is lower than firms having low-weight contracts. The abnormal return rate of high-weight is significant in month 7 (lower return than low-weight) and month 9 (higher return than low-weight). The abnormal return rate of low-weight is significant in month 1 (lower than highweight) and month 5 (also lower than high-weight). Therefore we conclude that the market value of firms announcing information technology agreements was more positively impacted for the firms having a high-weight contract than a low-weight contract. 
The impact of a long-term IT outsourcing contract (figure 2) on outsourcing firms' abnormal rate of return is higher except for month 1 and month 6. The significance level also supports higher abnormal return for firms having a long-term contract and thus we conclude that a long-term contract sends a positive sign to the stock market.

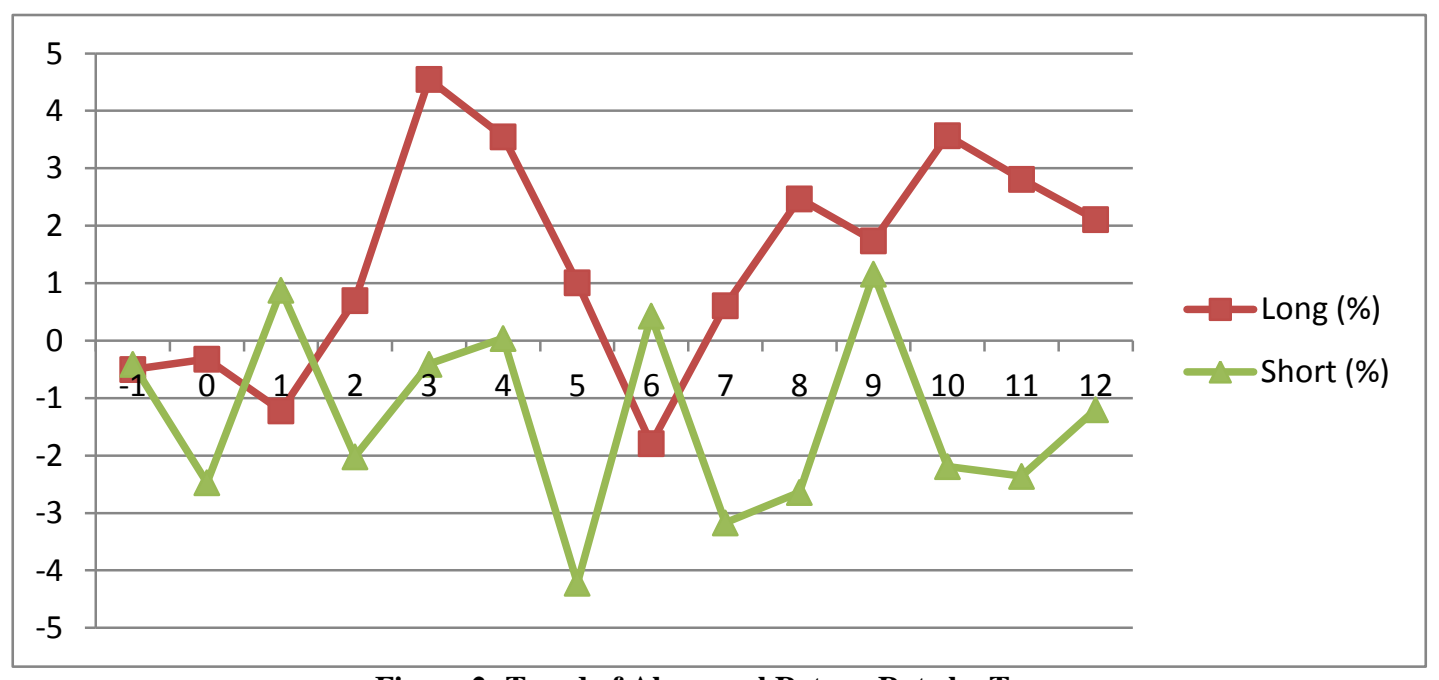

Figure 2: Trend of Abnormal Return Rate by Term

Table 6: Abnormal Return Results by Weight

\begin{tabular}{|c|c|c|c|c|c|c|c|c|c|c|c|c|c|c|}
\hline Month & -1 & 0 & 1 & 2 & 3 & 4 & 5 & 6 & 7 & 8 & 9 & 10 & 11 & 12 \\
\hline High (\%) & -0.04 & -1.14 & 1.90 & -2.33 & 2.57 & 1.53 & -0.33 & -1.65 & -2.69 & -1.64 & 2.09 & 0.25 & 0.80 & 0.88 \\
\hline Zvalue $(\mathrm{H})$ & $-1.87 *$ & -0.97 & -0.37 & -1.13 & 0.09 & -1.13 & -1.13 & 0.25 & $-1.30 \$$ & -0.84 & $1.97 *$ & 0.09 & 0.72 & 0.41 \\
\hline Low $(\%)$ & -0.97 & -2.10 & -2.48 & 1.09 & 0.67 & 1.60 & -4.06 & 0.87 & -0.01 & 1.07 & 0.55 & 0.35 & -1.37 & -0.64 \\
\hline Zvalue (L) & $\begin{array}{l}-1.02 \\
\end{array}$ & 0.35 & $-1.37 \$$ & $\begin{array}{l}-0.17 \\
\end{array}$ & $\begin{array}{l}-0.17 \\
\end{array}$ & 1.22 & $-2.95 * *$ & -1.21 & -0.17 & 0.88 & -0.70 & -0.18 & -1.25 & -0.18 \\
\hline
\end{tabular}

The symbols $\$, *, * *$, and $* * *$ denote statistical significance at the $0.10,0.05,0.01$, and 0.001 levels, respectively, using a generic one-tail test

\begin{tabular}{|c|c|c|c|c|c|c|c|c|c|c|c|c|c|c|}
\hline & & & & & & & & & & & & & & \\
\hline Month & -1 & 0 & 1 & 2 & 3 & 4 & 5 & 6 & 7 & 8 & 9 & 10 & 11 & 12 \\
\hline Long (\%) & -0.50 & -0.32 & -1.22 & 0.70 & 4.55 & 3.55 & 1.01 & -1.79 & 0.61 & 2.47 & 1.74 & 3.57 & 2.81 & 2.11 \\
\hline Zvalue(LG) & $-1.64 \$$ & 0.10 & $-1.30 \$$ & -0.25 & -0.25 & 0.45 & $-1.64 \$$ & -0.95 & 0.10 & 0.63 & $1.34 \$$ & 0.82 & 0.46 & 0.46 \\
\hline Short $(\%)$ & -0.41 & -2.47 & 0.88 & -2.02 & $\begin{array}{l}-0.41 \\
\end{array}$ & 0.04 & -4.22 & 0.43 & -3.17 & -2.64 & 1.16 & -2.19 & -2.36 & -1.20 \\
\hline Zvalue(S) & $-1.34 \$$ & -0.74 & -0.44 & -1.06 & 0.16 & -0.45 & $-2.28^{*}$ & 0.01 & $-1.54 \$$ & -0.61 & 0.16 & -0.78 & -0.78 & -0.15 \\
\hline
\end{tabular}

The symbols $\$, * * *$, and $* * *$ denote statistical significance at the $0.10,0.05,0.01$, and 0.001 levels, respectively, using a generic one-tail test

Jiang et al (2007) stated that short-term duration contracts signal that the risk of outsourcing is controllable and will demonstrate a positive signal to the stock market compared to long-term outsourcing. Furthermore, lowvalue contracts will also have lower risk. Our explanation for the deviation between our results and an earlier conceptual result is perhaps due to a change in the trend of the IT outsourcing industry. The IT outsourcing industry is becoming more mature and most of the vendors have quality assurance certifications like CMM, SEI and ISO, indicating the management competency in software development and product quality (Khan et al. 2003). The quality assurance and maturity level decrease the risk level significantly for high-value and long-term contracts. The highvalue and long-term contract will have higher returns and more profitability. In these contracts a supplier can provide new technology to an outsourcing firm at a lower cost and faster rate with better economy of scale (Quinn and Hilmer 1994). By giving a long term contract to vendors, outsourcing firms can use their resources for their core activities. Higher returns motivate the stock market to react positively. The test results do not support hypothesis $\mathrm{H} 1 \mathrm{c}$ and H1d. 


\section{CONCLUSION}

\section{Limitations and directions for future research}

It is necessary to address the limitations of this study and highlight the areas for future research. The archival financial data limits our analysis to what is available in public data bases. The financial data represent firms as a whole, with no information included on separate IT department or division. In the COMPUSTAT database, a few data, such as cash and equivalent on a quarterly basis, are not available, which limited our analysis. Furthermore, our analysis was limited to large public firms because the trade press reports only major outsourcing agreements.

IT budget data are not available and the results may differ for firms with different IT budget levels. In the future if such data become available, researchers may determine whether the findings of this study hold for various IT budget levels.

Our analysis is limited to contract type such as long-term, short-term, and high-value, low-value. Furthermore, risk analysis may be extended to onshoring-offshoring, and limited scope to multiple systems. Different client and supplier configurations such as single client - single vendor, multiple clients - single vendor, single client - multiple vendors, and multiple clients - multiple vendors have different associated level of risks.

Researchers get direct answers to their research questions through case studies and surveys, while the archival data analysis is objective and measures the performance through financial metrics. The combined study of archival data analysis and case study or survey may help to get better outsourcing results.

Financial researchers are finding a way to solve the misspecification of the long-run event study. There are two methods to solve such problems: One method uses a traditional event study framework to calculate the abnormal returns using a constructed reference portfolio. In another method, the mean monthly abnormal returns are calculated using calendar-time portfolios and a time-series t statistic. Kothari and Warmer (1997) suggest that these methods "seem like a promising framework for alternative tests which can potentially reduce misspecification." In the future, researchers can find a trustworthy long-run event study method to calculate the exact impact of outsourcing on firms' value.

\section{Findings}

We analyzed the effect of both weight and term on outsourcing firms' performance and value. This study provides objective, quantifiable evidence about the performance of IT outsourcing based on an assessment of audited accounting data rather perception-based analysis.

Our study shows that risk control plays an important role in outsourcing contract implementation. A relatively short-term and low-value outsourcing contract often achieves positive outcomes. Some analysts say that outsourcing gives the customer greater financial flexibility; however, a 10-year contract may actually restrict flexibility and increase costs. Renegotiating any contract could become far more expensive than changing internal commitments. Our results support the Theory of Transaction Cost's argument about uncertainty and the Agency Theory's argument that outsourcing firms prefer an outcome-based contract. In our risk analysis, we observed support for the improved performance by firms that provide short-term and low-weight contracts to vendors. A longterm and high-value contract may actually restrict flexibility and increase costs. The majority of the firms surveyed also indicated that their strategic focus was limited to three years because customer demand information and projections on costs and future technology were so hard to predict.

This study makes several contributions to both practice and theory. This research empirically examines the link between IT outsourcing implementation and firm's operational and financial performance in different type of outsourcing contracts. 


\section{AUTHOR INFORMATION}

Pushpa Agrawal received her M. A. in Economics and Bachelor of Education from the University of Indore, India, MBA in Accounting from the University of Nebraska at Kearney, and is working on her doctoral dissertation at Singhania University, India. Her areas of interest are economics and accounting. She has presented papers at national DSI, Midwest DSI, and Mountain Plain Management Association conferences. E-mail: agrawalvk@unk.edu. Corresponding author.

Abid Haleem is a Professor at Jamia Millia Islamia, India. After receiving his Master of Science in Industrial Engineering from Aligarh Muslim University, India, he went to Indian Institute of Technology, New Delhi for his $\mathrm{PhD}$ in Mechanical Engineering. His areas of interest are operations management, technology management, and egovernance. His research has been published in journals such as Global Institute of Flexible Systems Management, International Journal Electronic Governance, Journal of Engineering Design and Technology, and International Journal of Computer Science and Systems Analysis. E-mail: haleem.abid@ gmail.com

\section{REFERENCES}

1. Aubert, B., Dussault, S., Patry, M., and Rivard, S. (1999). Managing the risk of IT sourcing. Paper presented at the proceedings of the $32^{\text {nd }}$ Hawaii International Conference of System Sciences (HICSS), January 5-8, Hawaii.

2. Bahli, B. and Rivard, S. (2003).The information technology outsourcing risks: A transaction cost and agency theory-based perspective. Journal of Information Technology, 18, pp. 211-221.

3. Bandwin, Jane and Glezen, G. William (1992). Bankruptcy prediction using quarterly financial statement data. Journal of Accounting, Auditing \& Finance, Vol. 7, Iss. 3, pp. 269-285.

4. Barth, Mary E., Cram, Donald P., and Nelson, Karen K. (2001). Accruals and the prediction of future cash flows. The Accounting Review, Vol. 76, No. 1, January, pp. 27-58.

5. Barthelemy, J. (2001). The hidden cost of IT outsourcing. Sloan Management Review, Vol. 42, Issue 3, pp. 60-69.

6. Beaver, W.H. (1998). Financial reporting in accounting revolution. Upper Saddle River, NJ: Prentice Hall

7. Bengtsson, Lars, and Dabhilkar, Mandar (2009). Manufacturing outsourcing and its effect on plant performance - Lessons from KIBS outsourcing. Journal of Evolutionary Economics, 19: 231-257.

8. Boehm, B.W. (1981). Software engineering economics. Englewood Cliffs, NJ: Prentice Hall.

9. Chen, Q., Tu, Q., and Lin, B. (2002). Global IT/IS outsourcing: Expectations, considerations, and implications. Advances in Competitiveness Research, 10(1), pp. 100-111.

10. Domberger, S. (1998). The contracting organization: A strategic guide to outsourcing. Oxford University Press, Oxford.

11. Dou, Y. and Sarkis, J. (2010). A joint location and outsourcing sustainability analysis for a strategic offshore decision. International Journal of Production Research, Vol. 48, No. 2, 15 January, pp. 567-592.

12. Earl, M.J. (1996). The risk of outsourcing IT. Sloan Management Review, Spring, pp. 26-32.

13. Evaristo, R., Nicolas, J., Prikladnicki, R., and Avritchir, J. (2005). Wholly owned offshoring subsidiaries for IT development: A program of research. Paper presented at the Proceedings of the $38^{\text {th }}$ Hawaii International Conference of System Sciences (HICSS), January 3-6, Hawaii.

14. Gartner (2011). Forecast alert: IT spending, worldwide, 2008-2014,4Q10 update, 4 January, retrieved on February 9, 2011, http://www.gartner.com/DisplayDocument?doc cd=209967\&ref=g reghm

15. Grover, V., Cheon, M.J., and Teng, J.T.C. (1996). The effect of service quality and partnership on the outsourcing of information systems functions. Journal of Management Information Systems, Vol. 28, No. 2, pp. 397-425.

16. Hall, James A. and Liedtka, S.L. (2005). Financial performance, CEO compensation, and large-scale information technology outsourcing decisions. Journal of Management Information Systems, Summer, Vol. 22, No. 1, pp. 193-221.

17. Hayes, David C., Hunton, James E., Reck, J.L. (2000). Information systems outsourcing announcements investigating the impact on the market value of contract-granting firms. Journal of Information Systems, Vol. 14, No. 2, pp. 109-125. 
18. Hendricks, K.B. and Singhal, V.R. (2003). The effect of supply chain glitches on shareholder wealth. Journal of Operations Management, Vol. 21, pp. 501-522.

19. Jiang, B., Frazier, G.V., and Prater, E.L. (2006). Outsourcing effects on firm's operational performance: An empirical study. International Journal of Operations and Production Management, Vol. 26, No. 12 pp. 1280-1300.

20. Jiang, B., Belohlav, J.A., and Young, S.T. (2007). Outsourcing impact on manufacturing firms' value: Evidence from Japan. Journal of Operations Management, 25, pp. 885-900.

21. Johnson, R. (2000). Breakaway - handing off a job: Outsourcing is tempting but beware the pitfalls. The Wall Street Journal, September 25.

22. Khan, Naureen, Currie, Wendy L., Weerakkody, Vishanth, Desai, Bhavini (2003). Evaluating offshore IT outsourcing in India: Supplier and customer scenarios. Proceedings of the $36^{\text {th }}$ Hawaii International Conference on Systems Science.

23. Kothari, S.P. and Warner, J.B. (1997). Measuring long-horizon security price performance. Journal of Financial Economics, Vol. 43, pp. 301-339.

24. Lacity, M.C. and Hirschheim, R. (1993). The information systems outsourcing bandwagon. Sloan Management Review, Fall, 35.1, pp. 73-86.

25. Lacity, M.C. and Willcocks, L.P. (1996). The value of selective IT sourcing. Sloan Management Review, Vol. 37, Iss. 3, pp. 13-25.

26. Lacity, M.C. and Willicocks, D.L.P. (2001). Global information technology outsourcing. New York: John Wiley \& Sons.

27. Legorreta, L. and Goyal R. (2007). Managing risks of IT outsourcing in Outsourcing Management Information Systems, (Etd. Mark J. Schniederjans, Ashlyn M. Schniederjans, and Dara G. Schniederjans), Idea Group Publishing, PA: Hershey

28. McCarthy, I. and Anagnostou, A. (2003). The impact of outsourcing on the transaction costs and boundaries of manufacturing. International Journal of Production Economics, 88, pp. 61-71.

29. Mucisko, D., and Lum, E. (2005). Outsourcing falling from favor with world's largest organizations. Deloitte Consulting LLP Report, April.

30. PA Consulting Group (PACG) (1996). Riding the wave of channel substitution. PACG, London.

31. Paul, D.L. and Wooster, R.B. (2010). An impirical analysis of motives for offshore outsourcing by U.S. firms. The International Trade Journal, Vol. 24, No. 3, July-September, pp. 298-320.

32. Prahalad, C.K. and Hamel, G. (1990). The core competence of the corporation. Harvard Business Review, May-June, pp. 79-91.

33. Quinn, J.B. and Hilmer, F.G. (1994). Strategic outsourcing. Sloan Management Review, Vol. 35, No. 4. Summer.

34. Ramchandran, V., and Gopal, A. (2010). Managers' judgments of performance in IT services outsourcing. Journal of Management Information Systems, Spring, Vol. 26, No. 4, pp. 181-218.

35. Shah, A. (2011). Gartner upgrades worldwide IT spending forecast. Computerworld, June 30.

36. Smith, M.A., Mitra, S., and Narasimhan, S. (1998). Information systems outsourcing: A study of pre-event firm characteristics. Journal of Management Information Systems, Fall, Vol. 15, No. 2, pp. 61-93.

37. Teece, D. (1987). Capturing value from technological innovation: Integration, strategic partnering, and licensing decisions. In B. Guile \& H Brooks (Eds.), Technology and global industry, Washington: National Academy Press.

38. Wang, Li, Gwebu, K.L., Wang, J., and Zhu, D.X. (2008). The aftermath of information technology: An empirical study of firm performance following outsourcing decisions, Journal of Information Systems, Vol. 22, No. 1, Spring, pp. 125-159.

39. Windrum, P., Reinstaller, A., and Bull, C. (2009). The outsourcing productivity paradox: Total outsourcing, organizational innovation, and long run productivity growth. Journal of Evolution Economics, 19, pp. 197229. 